\title{
Organizational innovation in the context of family farms: lean diagnosis
}

\author{
Ana A. Aguiar \\ aaguiar@fc.up.pt| GreenUPorto - Research Centre for Sustainable for Agrifood Production \& DGAOT, \\ Faculty of Sciences, University of Porto. Campus de Vairão, Rua da Agrária 747, 4485-646 Vairão, \\ Portugal. \\ Luísa Silva \\ luisasilva1940@gmail.com | GreenUPorto - Research Centre for Sustainable for Agrifood Production \& \\ DGAOT, Faculty of Sciences, University of Porto. Portugal. \\ Cristina Parente \\ cparente@letras.up.pt | Departamento de Sociologia e Instituto de Sociologia, Faculdade de Letras da \\ Universidade do Porto, Porto, Portugal \\ Cristina A. Costa \\ amarocosta@esav.ipv.pt | CI\&DETS and CERNAS Research Centres, ESAV, Instituto Politécnico de \\ Viseu, Portugal.
}

\begin{abstract}
Family farming has been on the agenda worldwide. Portugal is no exception. Act No. 64/2018, published in 2018, establishes the Family Farming Statute. Its preponderance in food and in the sustainability of families and territories has been reinforced by the sustainable development paradigm. However, competitiveness constraints assigned to the production system is often seen as an obstacle. Combining the theoretical frameworks of integrated agriculture and work organizations, we offer a lean sociological perspective on family farms producing lettuce. We concluded that their production system is characterized by a set of innovative practices very close to a lean approach. However, there is room for improvements in a production system that seems to maintain a family-based workforce and traditional know-how.
\end{abstract}

Keywords. Lean production; Family farming; Portugal; Integrated production; Agriculture.

Cite paper as: Aguiar, A., Silva, L., Parente, C., Costa, C., (2020). Organizational innovation in the context of family farms: lean diagnosis, Journal of Innovation Management, www.open-jim.org, 8(2), 68-86. 


\section{Introduction}

Family farming is considered uncompetitive due to a multiplicity of constraints pointed out in literature. Among these, the farmers' lack the technical and technological knowledge that would enable them to successfully plan the desired results and efficiently control production costs (Auerbach et al., 2013).

Worldwide, Lowder et al. (2014) report that of the 570 million farms, more than 500 million fall under the concept of family farming since their area is inferior to 2 hectares. They account for $90 \%$ of the world's farms and produce more than $70 \%$ of the food consumed, warranting the livelihoods of $40 \%$ of the families (Lowderet al., 2014).

Also in Portugal, according to the 2009 Agricultural Census, more than 750 thousand people work in family farms. These represent more than $90 \%$ of the total agro-rural holdings, with a used agricultural area of more than $55 \%$ of the national area and are responsible for more than $50 \%$ of the country's production (INE, 2011).

The importance of family farming and the limitations of competitiveness imputed to its production system led us to question the work organization models on which production is based. The theoretical approach used for the analysis was that of lean production, based on continuous improvement and the minimization of waste. This methodology first appeared in the Japanese industrial world. It has been tested in the agricultural sector in some countries (namely, the United States and Brazil) and represents an organizational innovation with positive results on the competitiveness and long-term sustainability of this type of businesses (Hartman, 2015; Mancini et al.,2016).

In times and regions where economy is more prosperous and employment shortages are lower, as is the current situation in the north of Portugal, the lack of manpower available for agricultural activity is often a major obstacle for small farms. A key requirement of competitiveness for the farmer and family owner is the rational organization of work (GPP, 2017). Considering, just as Mention et al. (2019) that innovation is a transversal desire to all companies as it represents an improvement in their performance, a study was made about process innovation, mainly of an incremental (try to do better) more than radical type (do different). Spacek \& Vacik (2016) in a case study in a diferente economic area show that efficiency creates value for the company.

We adopted an interdisciplinary approach that combines the theoretical and epistemological assumptions of agronomy, particularly of sustainable agriculture, and of the sociology of work and organizations with regard to work organization models and the premises of productive effectiveness and efficiency. Our main objective is to understand how can family farms become more competitive by adopting the principles of lean thinking in the organization of work without undermining a territorial model based on sustainable development. That is, ensuring economic efficiency without disrespecting natural and human resources, namely nature and workers. Using a qualitative methodology, we discuss the results of field observation in two family farms in the Portuguese coastal north. We wanted to know whether the work processes were close to, or distant from work rationalization techniques capable of promoting a more competitive agricultural production in family farms. 
The relevance of the study lies in the importance of family farming in terms of agricultural production, household income and its decisive contribution to the balance of the ecosystem, the preservation and enhancement of native species and the promotion of short production and consumption circuits. These are key aspects of environmental sustainability.

\section{Family farming and production systems}

According to FAO (2014), family farming has a key role in economic, environmental, social and cultural development.

Although the concept of family farming varies across countries (Suess-Reyes and Fuetsch, 2016), it is commonly accepted that it is a farming system based on small farms, mostly dependent on family labor and usually rooted in traditional practices. These small holdings (less than 2 ha) account for $12 \%$ of the world's agricultural area - about 30 to $40 \%$ in developing countries and $10 \%$ in developed countries (Lowderet al., 2016).

Recently, family farming has become a topic of public interest following the UN's recognition of its fundamental role in the sustainable development of territories and its declaration of 2014 as the International Year of Family Farming (FAO, 2014).

According to the FAO (2014), family and small-scale farming is closely linked to global food security, the preservation of traditional foods, a balanced diet, the preservation of agrobiodiversity and the sustainable use of natural resources. It offers an opportunity to stimulate local economies, especially when combined with specific policies designed to promote the social protection and well-being of communities.

More recently, in November 2017, the European Commission, in its communication to the European Parliament on the "Future of Food and Agriculture", stated that the evolution of agriculture aid includes "maintaining its market orientation and its support for the EU family farm model in all regions of the Union" (FAO, 2017).

Generally, family farming is linked to traditional production systems based on ancestral knowledge handed down from generation to generation and strong local roots. With the scientific and technological development occurred in the first half of the twentieth century, agriculture underwent great changes and began to use high quantities of production factors. In addition to machines, fertilizers and synthetic pesticides offer high rates of productivity and worldwide marketing. This strategy, known as industrial and / or conventional agriculture, is based on an intensive production system that has caused major environmental problems such as soil and water pollution, intoxication and loss of food quality. With the approaching 21st century and a growing ecological awareness and societal commitment, other production systems emerge that integrate new results of science, knowledge of other disciplinary areas and traditional ancestral knowledge. Sustainable agriculture can be seen as a development that meets current needs without compromising the ability of future generations to meet their own (WCED, 1987; Gold, 2007). The following sustainable production systems stand out: precision agriculture (Bongiovanni and Lowenberg-Deboer, 2004), integrated production (Freier and Boller, 2009), organic farming (IFOAM, 2020) and biodynamic agriculture (Biodynamics Association, 2020). In preci- 
sion agriculture, geographic positioning systems (GPS), geographic information systems (GIS), sensors and very sophisticated equipment are used in large and very large farms in extensive agriculture. In integrated production, natural resources are used to ensure long-term viable production. Any decision making is made after an evaluation of the action's indispensability and previously defined levels (thresholds). Chemical control is the last option (Stenberg, 2017). Organic farming is a way of producing high quality food and fiber using sustainable practices and rejecting synthetic pesticides and fertilizers. It is a type of agriculture that uses preventive and cultural methods such as crop rotation, intercropping and composting prioritizing soil care, pest and predator balance and recognizing the value of diversity and preservation of cultivars at risk. It is based on four principles: health, ecology, justice and precaution (IFOAM, 2020). Biodynamic agriculture integrates all the principles and requirements of organic farming and other traditional knowledge materialized in the use of preparations to improve soil and plants and a calendar of activities inspired by astrological information that provides indications of optimal dates and times for different operations respecting ecological and ethical principles (Paull, 2011).

The production system is at the farmer's discretion. The latter's choice is strongly determined by internal factors - personal beliefs, knowledge and routines -, as well as external factors either the buyer's demands, the limitations of the activity itself or its location. For example, a small farm is unlikely to be able to acquire precision farming equipment or services and a farm located in a region where available irrigation water is contaminated with synthetic pesticides and fertilizers will not be able to adhere to organic or biodynamic agriculture.

In small-scale farms, as is the case of family farms, one way of making farming viable is to diversify supply and adopt the organic production system, thus being able to enter a market differentiated by quality.

In situations where the family farm does not adhere to organic production by option or impossibility, capitalization must be attained by another route. This is the case of horticultural farms located on the NW coast of Portugal between Esposende and Póvoa where, due to bad past agricultural practices, the aquifer supplying the whole area for irrigation is contaminated with high amounts of fertilizers and pesticides (Melo et al., 2012). This area where 100 years ago, in a time of food scarcity, human ingenuity built agricultural land on sandbanks is a place of intensive vegetable production all year round. Crops follow each other uninterruptedly occupying the entire available area and the cultural intensity requires fertilizers and pesticides in order to guarantee the desired productivity. As a result of growing ecological awareness, agricultural practices are changing and it is nowadays more common to opt for the so-called integrated production system (Aguiar, 2011). These farmers regularly conduct soil and water analyzes and use alternatives to chemical control such as biological control practices. The vegetables produced in this region are sold to the main supermarket chains competing directly with the large farms in the south of the country or in Spain (Silva, 2020). Our analysis focuses on these farms. It is based on the theoretical hypothesis that, in order to be competitive, the small family farmer common in this region must innovate in terms of work organization in an integrated production system. The lean approach is a path of organizational innovation. 


\section{Organizational innovation}

The word innovation became popular in the 1980s in Western countries. It was first used in industrial and technological policies (Guimarães, 1998) with instrumental objectives. In this line, it was allocated to knowledge production in economy and assumed an eminently technological feature. Scientific studies on innovation tend to show a strong trend to typifications according to different classification criteria: product and process innovation and more recently in distribution; incremental, radical and more recently disruptive innovation (eg. Nelson and Winter, 1982; Christensen, 1997). These two typologies, among others, have been revisited and remodelled in order to become heuristically effective to account for the evolution of socio-economic structures. The same can be said about the notion of change that is similar to that of innovation (Damanpour, 2017). The latter "follows both historically and theoretically the notion of change, widely developed within the classical issues of Industrial, Organizations and Work Sociology" (Parente, 2005). With regard to the Sociology of Work, organizational innovation, formerly called organizational change, refers to forms of work organization primarily associated with the socio-technical approach as alternatives to Taylorism and Fayolism (Ortsman, 1978) and, later, to toyotism and lean production (Coriat, 1993). As for management, it appears associated with the notion of organizational learning (Parente, 2008).

Whatever the discipline, technological innovation has been privileged in innovation studies (Damanpour and Aravind, 2012), insofar as, as Drucker (1985) stressed, innovation is primarily triggered by economic motivations. The sociology of work warns that there is no mechanical and deterministic relationship between technological innovation and productivity and growth. The refusal of technological determinism by sociologists since the 1970s, namely with the works of the so-called Critical Sociology, has only recently echoed in managent and business. Technological innovation alone represents a potential for productivity and growth that is all the more enhanced if associated with organizational innovation.

This explains why the analysis of other aspects of innovation, namely the organizational and social dimensions, is more recent (D' Iribarne, 1987). This was pointed out by the Green Paper on Innovation in 1995. It stated that one of the main weaknesses of European innovation systems was organizational innovation, "which does not allow the renewal of currently ineffective models" (Comissão Europeia, 1995).

The concept of innovation from a not only economic, but also socio-organizational perspective goes back to Schumpeter. For him, in 1934, to innovate was to revolutionize production routines benefiting from previously unknown possibilities (Schumpeter, 1996). Schumpeter's definition of innovation is broader and goes beyond technological innovation. According to Kanter (1983), "it allows thinking of innovation as 'the process of bringing and putting into use any form of problem solving'" (in Fonseca et al., 1996, p. 195). Innovation can be thought of as a "different way of doing things" (Fonseca et al., 1996, p. 194). As for its organizational dimension, the definition of innovation of the Oslo Manual "comprises three mains branches: (1) business practices (new methods for organizing routines and procedures); (2) workplace organization (new ways of distributing responsibilities involving employees); and (3) external relations (new ways of organizing relations with other firms or public institutions) (Alves et al., 2018). 
In line with the studies of the Sociology of Work, in this article, organizational innovation refers to routines and work organization processes associated with new forms of work organization. In this context, the Japanese models of organization (discussed in the following section) are often seen as an optimization of the classic proposals of the scientific organization of F. Taylor and H. Ford, even though they are still criticized for paying little attention to the equally impoverished work content and low worker empowerment.

\section{Work organization: from classic industrial models to the trans- versal approaches of lean thinking}

Work organization was first considered by industrial engineers. The first methodologies of work organization were formalized by xFrederick Taylor and Frank Gilbreth in the early twentieth century. Task fragmentation and the strict control of workers' movements were seen as beneficial. The study of work organization continued with Henry Ford who introduced a mechanical conveyor in the Taylor assembly chain making continuous and mass production possible. In the 1950s, Taiichi Ohno, an engineer born in China, sought to create competitive advantages through the optimization and improvement of work processes, developing this methodology with great success in the Toyota factory - the Toyota Production System.

However, it was in 1990 that the lean philosophy became known worldwide after the publication of the book "The Machine That Changed the World" written by James. P. Womack in partnership with Daniel T. Jones and Daniel Roos. The book presents a study of the Japanese automobile industry, especially Toyota, focused on the reduction of unproductive times and waste (Womack et al.,2007).

Lean production has evolved into a lean thinking philosophy with five basic principles.

Principle 1 - Define value. The value can only be defined from the customer perspective. This is the starting point of lean thinking. It identifies what customers want and what they are willing to pay for. It is no use doing anything technically perfect if the customer does not value it.

Principle 2 - Identify the value stream. Activities, from product design to delivery, must be identified, mapped and ranked according to the value they create. Whenever possible, this should include suppliers. Activities that do not add value to the customer are eliminated. Where this is not possible, they should be standardized and reduced to the necessary minimum.

Principle 3 - Make the value flow. The steps in a process must be interconnected and synchronized so that there is flow between them, minimizing waiting times and batch creation. By reducing activities that do not add value, the process must evolve in order to become as fluid as possible. It is the just-in-time (JIT), a system in which production and movement occur as needed.

Principle 4 - Implement pull based production. Pull based production (or pull flow) indicates that the (internal or external) customer's order is the trigger to start the value and production flow: right product at the right time and in the right amount. It is based on the JIT system and the leveling of production (known as heijunka), thus reducing stocks to a minimum. 
Principle 5 - Strive for perfection continuously. The strive for perfection is achieved through a continuous improvement culture where each person in the Value Stream must identify and propose improvements in the process for which $\mathrm{s} /$ he is responsible in order to reduce or eliminate waste. In accomplishing the four principles mentioned above, the company will be contributing to the continuous improvement that refers to the concept of kaizen.

Taiichi Ohno, in his professional experience and application of the Lean model, found three obstacles in the application of the Toyota Production System. He called them "The three MU: Muda, Mura e Muri."

The insufficiency of standardization and rationalization creates waste (Muda), inconsistency (Mura) and irrationality (Muri) in procedures and working hours that eventually lead to the production of defective products (Ohno, 1988).

There are several lean implementation tools of which we will retain only those that will be applied in this work:

- Value Stream Mapping (VSM) consists of identifying all tasks undertaken from order placement by the customer until delivery. It is essentially a planning tool to identify waste and devise solutions to eliminate it (Rother and Shook, 1999). It analyzes activity duration and corresponding costs takiing them into account in management optimization (Pinto, 2014);

- Kaizen - corresponds to continuous improvement efforts implemented by all parties. Its main focus is waste elimination (Imai, 1986);

- MUDA (refers to waste) - Anything that does not add value is waste, so it must be reduced or eliminated (Pinto, 2014);

- MURA (what is variable; it refers to irregularities or inconsistencies) - Variation in requests for a process or operation prevents the creation of a stable base (Pinto, 2014);

- MURI (What is irrational; manifests itself through excess or scarcity) - The standardization of work (ensures that everyone follows the same procedure; renders processes more predictable, stable and controllable) (Pinto, 2014);

- " $5 \mathrm{~S}$ " or more recently the "6S" refer to a set of practices that seek to reduce waste and improve the performance of processes and people through a simple approach aimed at achieving optimal conditions in the workplace (Zu et al.,2008).

The practices have designations beginning with the letter S: Seiri(sort); Seiton(set in order); Seiso(shine); Seiketsu(standardize); Shitsuke(sustain) and the most recent "S" for safety. This lean instrument motivates workers to order, organize and tidy up the workplace and facilitates the waste reduction effort. Worker involvement tends to be high and the return of its application very visible.

The lean philosophy has been implemented in several economic sectors, namely in services, where it seeks to reduce waste, improve efficiency and increase productivity, nonetheless always focusing on its main objective of identifying the value to the customer (Levitt, 1972; Suárez-Barraza et al., 2012). However, references to its application in the agricultural sector are scarce.

Hartman (2015) explains how he applied this methodology to his 4 ha farm in Indiana, United 
States of America, where he produced vegetables. He believed that farmers worked hard and that it was possible to reduce wasted effort in tasks that did not add value to the final product, increase efficiency, maximize profit with less labor, and enjoy a more satisfying life. The author found two main types of waste on his farm: the necessary tasks, which do not add real value; and pure waste. The most controversial waste according to lean methodology is the first. For example, eliminating weeds does not add value but it is necessary.

Another study is that of Mancini et al(2016), who demonstrate the potential of this philosophy to improve small farm competitiveness. In this study, a small family producer whose main activity was lettuce production was chosen and exhaustively analyzed. They contacted this producer's main customer - a restaurant - to understand how the orders were placed and what represented value for the latter. They then visited the farm, followed the different phases of lettuce production and, after some information from the producer, elaborated the VSM. In this mapping, they identified the activities that added value, those which did not add value, but were necessary, and those that did not add value. After analyzing this tool and assuming that the producer should only produce what is requested by his/her client, a new VSM was elaborated eliminating pure waste (activities that did not add value) and suggesting some process changes to make it simpler and more continuous. They concluded that the use of lean philosophy in agriculture has great potential and offer competitive advantages to small farms (Mancini et al., 2016).

Motivated by these experiences and believing that family farms show potential for organizational innovations capable of improving their productivity, we have developed a diagnostic study to identify the extent to which work processes are close to or distant from lean approaches with the aim of offering recommendations for operational improvement.

\section{Methodological strategy}

In order to diagnose the work processes implemented in family farms based on the principles of lean thinking, we combined multiple case-studies in a cross-case analysis (Yin, 1994; Creswell, 1994) according to the qualitative paradigm (Denzin and Lincoln, 1994).

This is a multiple case-study of two similar cases in terms of lettuce culture. From the perspective of cross-case analysis, we resorted to a second case in order to ensure the validity of the analyzes carried out. These have been supported or rejected by a comparative and sequential approach. The fundamental choice lied in the culture to be studied, due either to the seasonal character of agricultural production or the farmers' willingness to demonstrate their operating modes during intensive labor times. Among the work processes observed on family farms, the lettuce crop was chosen for the following reasons: i) pre-existence of the Mancini et al.,(2016) study that allows us to share knowledge and experience; ii) it is grown almost all over the world and on all types of farm (family and industrial); iii) its strong presence in the region between Douro and Minho, where our study was conducted; iv) it can take place either during autumn-winter in greenhouses, or in the open air during spring-summer. These intentionally chosen characteristics facilitated the use of the indispensable observation protocols in a relatively unknown domain. 
Two family farms were randomly selected for the analysis of lettuce production. They are located in the area of Estela, Póvoa de Varzim, and produce vegetables. In both cases, the household revenue comes from agriculture and the workforce is predominantly composed of family members. Both adopted integrated production systems. On farm A, we observed the harvest of greenhouse lettuce during winter. On farm B, we observed the planting and harvest of lettuce produced outdoors during summer.

The main data collection techniques used were the systematic observation of work organization and verbal "why" and "how" protocols" (Bisseret et al.,1999) to question farmers about their activities. A check-list survey was also applied in order to understand: i) the farmers' sociodemographic characteristics and their relation to land and property; ii) the farm's characteristics (current parcels of the holding by numbers, areas, names; the presence of cover / greenhouse; current, previous, pre-previous, and pre- pre-previous crop to get information on culture rotation; people working in the farms); iii) agricultural practices related to crop protection - preventive and curative control methods including cultural, biological and chemical methods. The technical itinerary - "theoretical technical and technological models identifying the cultural operations, tasks and technologies to be used" (Amaro et al., 2000) - was also designed with the farmers. It identifies the orderly set of cultural operations and agricultural tasks associated with lettuce production.

The observation script containing the items to be observed and the questions to be asked to the farmers were prepared with the help of an expert - a lean consultant for the industrial sector who joined us during the observation period para auxiliar a implementação do raciocínio base do VSN.

Initially, it was necessary to identify: the most representative client for each culture; the type of client (cooperative, association, private company, supply market, local market, etc.); the type of contract between the parties; what did the client buy and how often; the distance between the parties; how were deliveries scheduled; how were they negotiated; whether deadlines were met; whether or not there were penalties for defaults (on the customer side); how were sales negotiated; who negotiated the sales; and the time consumed with this process. Additional issues, such as price, average sales per year, and the latter's influence on the price were also examined. All this information is decisive for a lean diagnosis.

Direct observation focused more on a portion of lettuce cultivation on each farm. The observation script had several parts, including plot identification (name, area, planting date and lettuce development considering the number of leaves) and the technical itinerary of the lettuce (machine organization and layout, machine distance, tools, risk protection and safety equipment, and garbage dumps).

The technical itinerary for lettuce has been studied taking into account the following analytical dimensions:

1. Soil preparation before the crop (soil disinfection, solarization, fertilization, mobilizations, plastic covering);

2. Planting (how are the plants obtained - mote, alveoli or other), planting tasks;

3. Cultural operations: 
- Irrigation (origin, type and frequency);

- Weed elimination (soil covered with plastic, herbicide spraying, hand or mechanical weed removal);

- Fertilization (direct application or fertigation and frequency);

- Culture protection (who assesses the risk, how is it done, who decides to treat, how many treatments are done);

4. Harvesting (how many times and for how long, including cutting, placing in boxes, washing and shipping).

For a more detailed analysis, we have decided to observe the operative modes during harvest on both farms and planting on one farm.

The triangulation of data collection techniques and the consequent data cross-checking and validation via cross-case analysis were central to expand case analysis and particularly useful in VSM analysis.

The observation records and the informal interviews with the farmers underwent a descriptive category content analysis. As we conducted the second observations and talked to the second farmers, we completed a transversal reading of the cases. This facilitated the creation of thematic categories as it expanded our understanding of the technical itinerary by establishing relationships between both contexts and revealing particularities and common aspects. The findings allowed further expansion and revisitation to the first case-study and generalization to the analyzed culture. The thematic categories were designed through data articulation. The analysis was systematized in a flow chart.

\section{Discussion}

\subsection{Characteristics of family farms}

Two farms were observed. Farm A has an area of 1.5 ha, with 0.5 ha of greenhouse, and farm $\mathrm{B}$ has an area of 2.35 ha, with 1.7 ha of greenhouse. Both farms have 5 plots distanced up to 5 $\mathrm{km}$. These two farms are similar to many others on the coast between Esposende and Póvoa de Varzim. The plots of cultivated land come from old "masseira" fields widened by the joining of continuous fields, allowing the installation of greenhouses and easier mechanization. Vegetables such as lettuce, tomato, pepper, green beans, zucchini, cucumber, onion, carrot, turnip and cabbage are almost continuously cultivated season after season, year after year. On farm A, the work focused on lettuce cultivation in greenhouse during winter and on farm B on lettuce cultivation outdoors during summer. In farm A, the owners and farmers are a couple, both 70 years old and with the 4-year compulsory at education their time. They are self-employed and work full time with no paid workforce. The owner of farm B is a 28-year-old man who devotes himself full-time to family farming. His mother is a full-time wage worker and his grandfather, who is retired, works as an unpaid worker. 


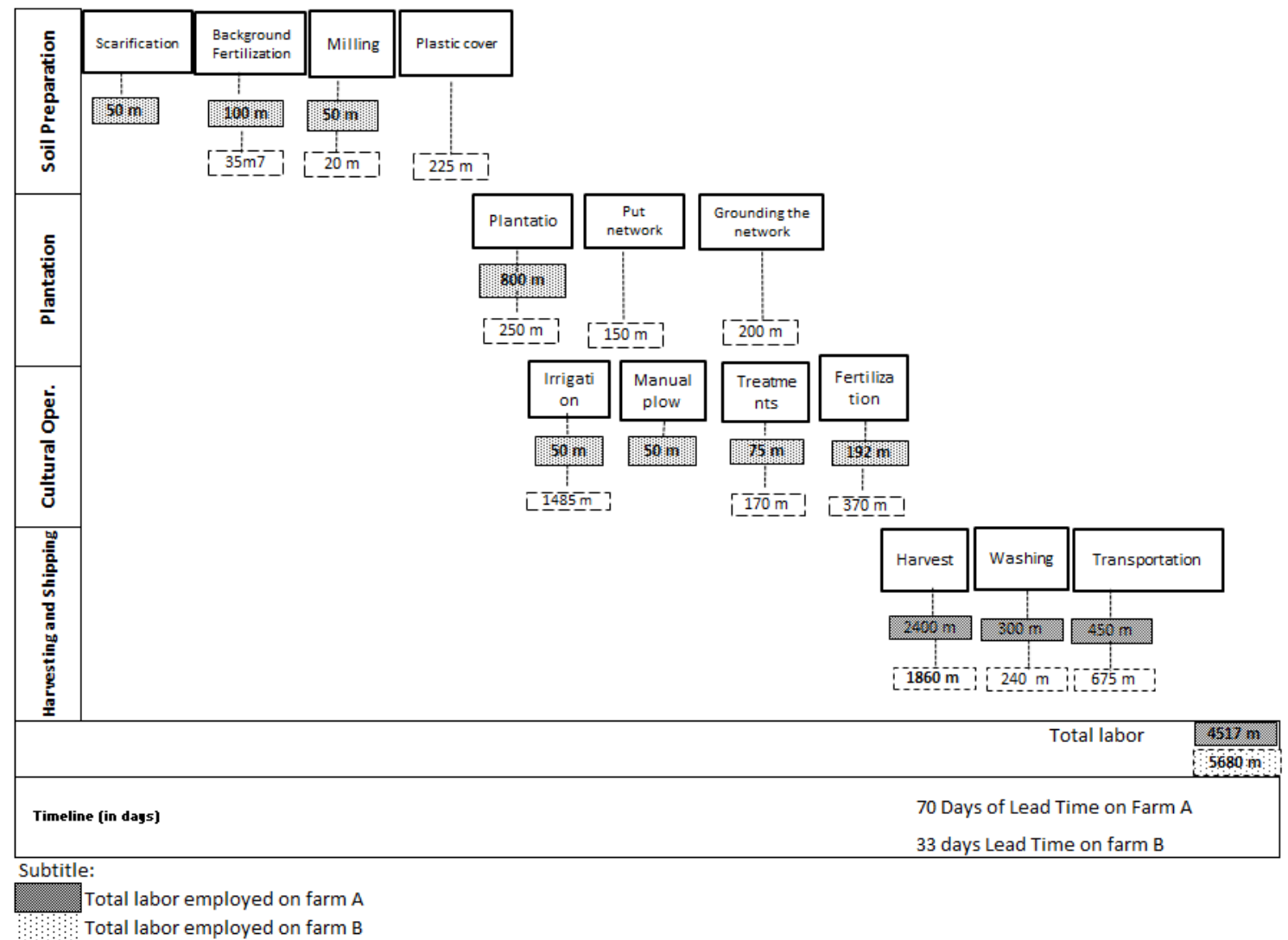

Fig. 1. - VSM of farms A and B

\subsection{Lean diagnosis}

VSM was performed for greenhouse and outdoor lettuce cultivation (Figure 1) by observing all phases of the productive process on farms A and B. For each cultures' mapping, we marked the operations performed and the execution times grouped in phases. Labor was counted in minutes. Whenever work was performed by more than one person, the recorded time was the sum of the time spent by each worker appointed to the operation.

The VMS presented shows all the organized operations and allows us to perceive the whole flow at a glance (bird eye), as Hartman (2015) did for a dairy farm in Denmark.

A more detailed study of lean methodology was applied to harvesting on farms A and B and to planting only on farm B. The results are presented in figures 2 and 3. Activities that add value and those that do not add value, but are necessary, as well as opportunities for improvement have been noted.

The lettuce lead time during the winter greenhouse was 70 days and the labor necessary to carry out all the cultural operations, reported to $1000 \mathrm{~m}^{2}$, was 75 hours and 17 minutes. The lettuce lead time during summer was 33 days and the labor necessary to carry out all cultural operations from land preparation to harvesting, reported to $1000 \mathrm{~m}^{2}$, was 94 hours and 40 minutes. 


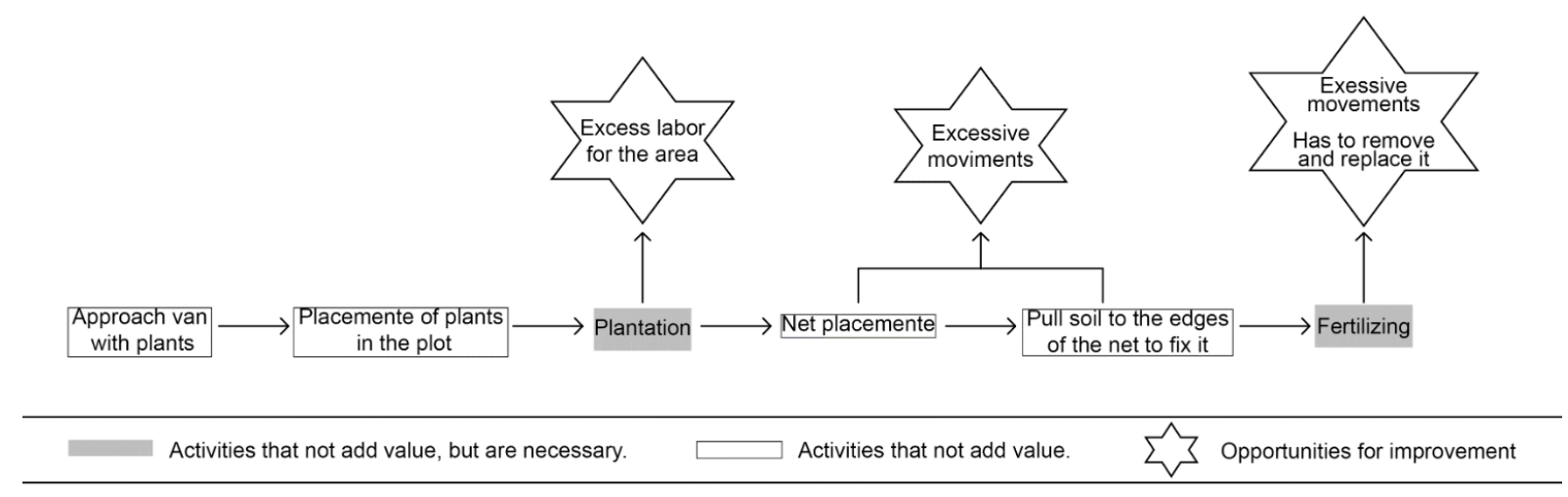

Fig. 2. Harvest flowchart of farms A and B

One major conclusion is that farmers already applied some lean principles on their farms. These included:

- The normalization of the boxes used during harvesting, a principle that facilitates the customer delivery format management;

- The van's proximity to the harvest space when picking the lettuces, which greatly reduces the farmers' movements and box transportation; this situation is very different from that observed by Mancini et al. (2016) who refers to the loss of time for travel.

- Training and standardization of harvesting work: growers harvested lettuce by exactly the same method. They knew how to cut and what leaves to remove. This meant, for example, that an entire lettuce would never be rendered unusable due to poor harvesting and it also made them faster and more productive; as mentioned by Hartman (2015), movements are rationalized for the harvest of tomatoes and cucumbers, the situation observed by us being very different from that observed by Mancini et al (2016), which points to lost time due to overwork and lack of labor.

- Relationship with the final customer was based on an agreement according to which producers are quite sure that they will sell everything they produce. Producing what is guaranteed to be sold greatly reduces the risk of difficulties in disposing of production. In other words, the irregularities and inconsistencies that the Japanese call muraare rather small. However, they are not null, and there may be excess production due to uncontrolled situations.

- Planting lettuce by plots at different times also favors harvests at different times for some time. This is an excellent example of the leveling of demand between consecutive operations, which greatly reduces the farm's muri and there are no unexpected workloads;

- Surface cleaning of lettuce rather than thorough washing because the customer does not value the first. This illustrates the advantage of clarifying what is value for the customer and avoiding waste of overprocessing.

As for improvement opportunities, we have identified: 


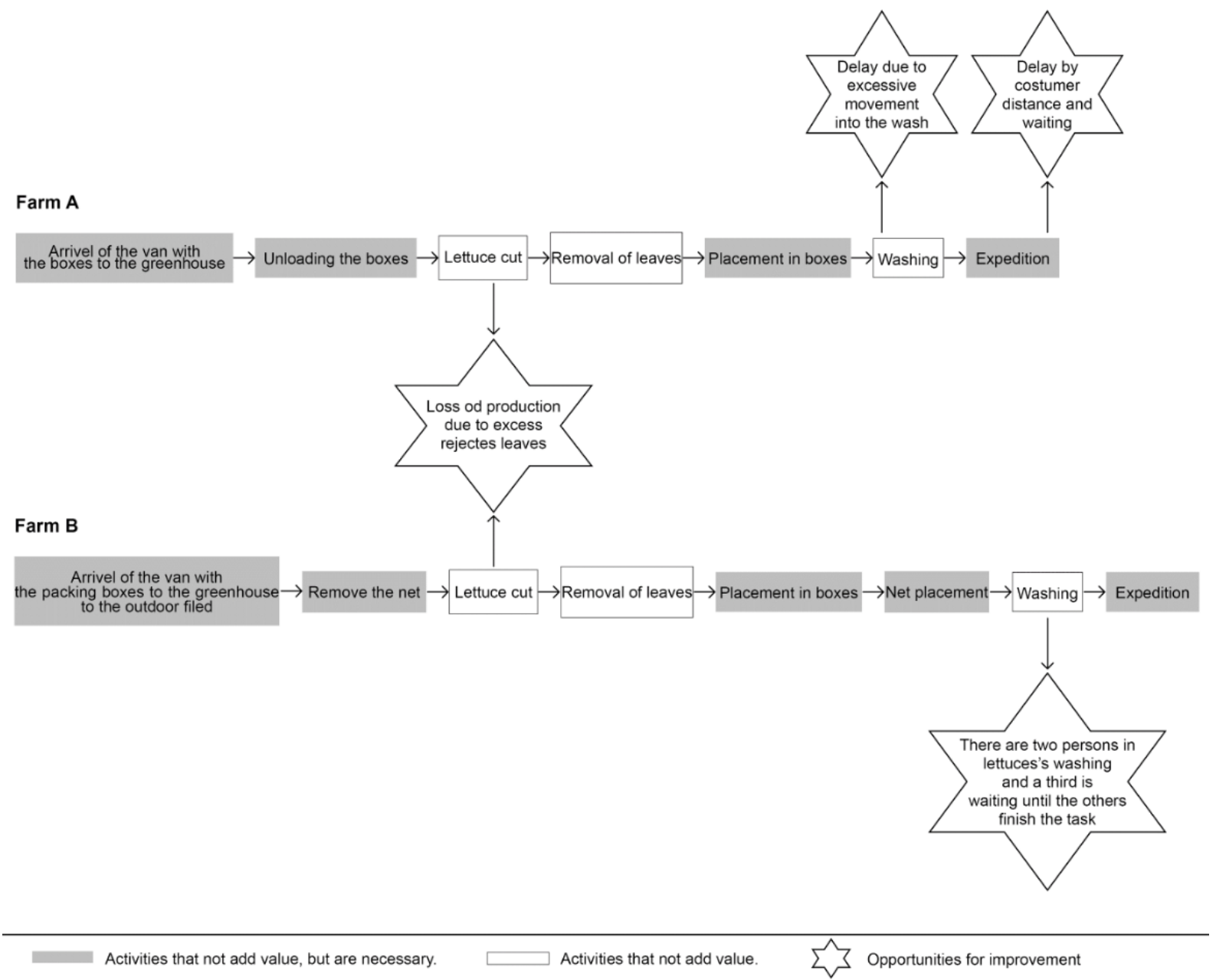

Fig. 3. Plantation flowchart of farm B

1. Loss of production due to an excess of rejected leaves, that is, during harvesting, on average, 6 leaves out of 50 of crisphead lettuce and 8 out of 48 leaves of butterhead lettuce were rejected. We wondered whether the lettuce variety influenced the number of rejected leaves and the answer was positive. One possibility to consider is to produce more crisphead lettuce (which implies fewer leaves rejected) to the detriment of varieties that lead to more losses.

2. Excessive manpower and unproductive times on farm B. Both during planting and harvesting, there were 3 people. However, most tasks were performed by 2 people simultaneously, which meant that one of the persons was temporarily unemployed. Planting would be more fluid if one of the workers distributed the plants so that these were closer to those who are planting. During planting, a delay of 1 hour and 40 minutes was recorded for the 
third person for an area of $1000 \mathrm{~m}^{2}$. During harvesting, this time raised to 7 hours and 45 minutes.

3. Excessive movements in laying the net on the open air plantation on farm B. The net's placement included extending it over the crop, placing pins in the corners for initial fixation and pulling sand up the edge of the net all the way around to fix it to the ground and prevent wind inlet. The last operation was done using the hands to hold the net down and the feet to move the sand. It is a laborious and delayed operation. In order to fix the net, and as an alternative to laying the sand with the feet, it would be possible either to use pins along the entire net length since their placement is simple and fast, or to place long quadrangular sticks on the net;

4. Excessive movements in lettuce washing on farm A. Lettuces are placed in boxes and put in the van, which then moves to the water point. Here, boxes are removed for washing (with the lettuces inside) and put back in the van. The movements linked to loading, unloading and reloading the boxes in the van could be reduced to a single movement if the washing operation was performed before the boxes were placed in the van with equipment that would not cause waterlogging inside the greenhouse.

5. Average lettuce delivery time to the customer was 45 minutes both on farm A and B because it depended on the number of producers arriving at the delivery site simultaneously. This time loss may be due to the negotiation of different delivery times.

\section{Conclusions}

On the family farms we analyzed, a set of practices seem close to lean methodology concepts, however in an unconscious and unintentional way. In spite of such similarity, there is room to improve operational efficiency.

A lean thinking approach, although not a complete novelty for these two farms, if deliberately implemented, could be a useful organizational innovation both in the awareness of how effective and efficient the family farmers' functioning is and how rationalization can be intensified and generalized to other operations, thus boosting competitiveness. There are some opportunities for improvement and adding value to the agricultural activity increasing its profitability and therefore potentiating endogenous territorial development.

This work has obvious limitations due to its exploratory character, including the scarce number of cases and planting and harvesting operations we have analyzed. However, thanks to an interdisciplinary combination of tools and knowledge, it provisionally suggests some opportunities for family agriculture through organizational innovation.

We believe that the farmers who were the object of this study have become aware of the possibilities for improvement and now have an opportunity to innovate by implementing one or more of the 5 recommendations arising from this study. By applying an innovative methodology to family farming, this study offered quantified values of work include in each cultivation operation, as well as of the total time (lead time). This constitutes a reference for future work on innovate practices or methods. 
However, we warn that improvements do not pervert a production system based on family, tradition and based on ancestral knowledge. This provides identity to agricultural activity, farmers and territories, and contributes to the conservation of the ecosystem.

This study was carried out with professional family farmers, that is, individuals for whom agriculture is the family's sole economic activity. It would be interesting to extend the study to family farmers for whom agriculture is a complementary economic activity.

\section{Acknowledgments}

We thank Engineer Vasco Pessoa Jorge who, with his experience in lean implementation in the industry, offered to prepare and follow the observations of this study.

This publication was supported by FCT - the Portuguese Foundation for Science and Technology, within the scope of UID/SOC/00727/2019, by Instituto de Sociologia da Universidade do Porto. The research was partially funded by de Portuguese bank Caixa Geral de Depósitos through the project "Bridges between familiar agriculture and organic farming" (PROJ/CIDETS/CGD/0006) https://agriculturabiofamiliar.wordpress.com/

\section{References}

Aguiar, A. (2011). Pest management in vegetable production in "masseira" field region. $I O B C / W$ PRS Bulletin, 65, 33-36.

Alves, M., Galina, S., \& Dobelin, S. (2018). Literature on organizational innovation: Past and future. Innovation $\& 5$ Management Review, 15(1), 2-19.

Amaro, F.S., Godinho, M.C., Figueiredo, E., \& Mexia, A. (2000). Itinerários técnicos e calendários culturais para culturas "em estufa" - região Agrária do Ribatejo e Oeste. Lisbon: Projeto Projecto PAMAF 6013, Instituto Superior de Agronomia.

Auerbach, R., Rundgren, G., \& Scialabba, N. (2013). Organic agriculture: African experiences in resilience and sustainability. Rome: Food and Agriculture Organization of the United Nations.

Biodynamics Association. (2020). What Is Biodynamics? Accessed 10 ${ }^{\text {th }}$ January 2020. https://www.biodynami is-biodynamics

Bisseret, A., Sebillotte, S. \& Falzon, P. (1999). Techniques pratiques pour l'étude des activités expertes. Toulouse: Octares Ed..

Bongiovanni, R., \& Lowenberg-Deboer, J. (2004). Precision Agriculture and Sustainability. Precision Agriculture, 5, 359-387.

Christensen, C. (1997). The innovation's dilemma. Boston: Harvard Business School Press.

Comissão Europeia. (1995). Livro verde sobre a inovação. Bruxelas: Ed. Comissão Europeia. 
Coriat, B. (1993). Pensar al revés. Trabajo y organizacíon en la empresa japonesa. Madrid: Siglo Veintiuno Editores.

Creswell, J. (1994). Research design: qualitative 83 quantitative approaches. Thousand Oaks: Sage Publications.

D' Iribarne, A. (1987). Innovation technique et innovation sociale: les enjeux de la compétitivité économique. Economie et Humanisme, 294(Mars/Avril), 67-79.

Damanpour, F. (2017). Organizational innovation. Oxford Research Encyclopedia of Business and Management. Oxford: Oxford University Press.

Damanpour, F., \& Aravind, D. (2012). Managerial innovation: Conceptions, processes, and antecedents. Management and Organization Review, 8(2), 423-454.

Denzin, N. K., \& Lincoln, Y. S. (1994). Handbook of qualitative research. London: Sage Publications.

Drucker, P. (1985). Innovation and Entrepreneurship. Oxford: Butterworth-Heinemann.

FAO. (2014). Family Farmers. Feeding the world, caring for the earth. Rome: Food and Agriculture Organization.

FAO. (2017). The Future of Food and Agriculture trends and challenges. Rome: Food and Agriculture Organization.

Fonseca, J.M., Cunha, M.P., \& Gonçalves, F. (1996). Inovação organizacional: perspetivas e níveis de análise. In A.C. Marques \& M.P. Cunha (Eds), Determinantes da gestão e relações com o mercado. Lisboa: Editora D. Quixote.

Freier, B., \& Boller, E.F. (2009). Integrated Pest Management in Europe - History, Policy, Achievements and Implementation. In: R. Peshin \& A.K. Dhawan (Eds), Integrated Pest Management: Dissemination and Impact. Dordrecht: Springer.

Gold, M.V. (Ed). (2007). Sustainable agriculture: definition and terms. National Agriculture Library, Brief series SRB 99-02.

GPP. (2017). Trabalho na Agricultura e novas tendências laborais. Lisboa: Gabinete de Planeamento, Políticas e Administração Geral. Série Cultivar, Cadernos de Análise e Perspetiva, (10).

Guimarães, R.A. (1998). Política industrial e tecnológica e sistemas de inovação. Oeiras: Celta Editores.

Hartman, B. (2015). The Lean farm: how to minimize waste, increase efficiency, and maximize value and profits with less work. Chelsea, USA: First Edition Green Publishing.

IFOAM. (2020). Definition of Organic Agriculture. IFOAM - Organics International. Accessed 10th January 2020. https://www.ifoam.bio/en/organic-landmarks/definition-organic-agriculture

Imai, M. (1986). Kaizen: The Key to Japan's Competitive Success. Irwin: McGraw-Hill.

INE. (2011). Recenseamento Agrícola 2009 - Análise dos Principais Resultados - Parte II. Lisboa: Instituto Nacional de Estatística. 
Kotler, P. (1999). Administração de marketing. S. Paulo: Edições Atlas.

Levitt, T. (1972). Production-line approach to service. Harvard Business Review, 50(5), 41-52.

Lowder, S., Skoet, J. \& Singh, S. (2014). What do we really know about the number and distribution of farms and family farms worldwide? Background paper for The State of Food and Agriculture 2014. ESA Working Paper, 14-02, 1-18.

Mancini, S., Fernandes, E., \& Athie, A. (2016). Agroecologia enxuta. $1^{o}$ Simpósio LusoBrasileiro sobre Modelos e Práticas de Sustentabilidade, Faculdade de Ciências e Tecnologia Universidade Nova de Lisboa, Portugal, 1-13.

Melo, A., Pinto, E., Aguiar, A., Mansilha, C., Pinho, O. \& Ferreira, I. (2012). Impact of intensive horticulture practices on groundwater content of nitrates, sodium, potassium and pesticides. Environmental Monitoring and Assessment, 184, 4539-4551.

Mention, A-L., Ferreira, J.J.P. \& Torkkeli, M. (2019). Towards the science of managing for innovation: conclusion \& future research directions. Journal of Innovation Management, 7(4),16 .

Nelson, R.R., \& Winter S.G. (1982). An evolutionary theory of economic change. Cambridge: Belknap Press.

Ohno, T. (1988). Toyota production system: beyond large-scale production. Oregon: Productivity Press.

Ortsman, O. (1978). Changer le travail. Les experiences, les methodes, les conditions de experimentation sociale. Paris: Dunod.

Parente, C. (2005). Inovação e/ou mudança - uma abordagem sociológica das controvérsias conceptuais. CadernosSociedade e Trabalho, 26, 63-79.

Parente, C. (2008). Produção de saberes profissionais: uma leitura a partir das teorias da mudança e aprendizagem organizacionais. Revista da Rede de Estudos do Trabalho, II(3), 128.

Paull, J. (2011). Biodynamic agriculture - the journey from Koberwitz to the world, 1924-1938. Journal of Organic Systems, 6(1), 27-41.

Pinto, J.P. (2014). Pensamento Lean: A filosofia das organizações vencedoras. Lisboa: Lidel.

Rother, M., \& Shook, J. (1999). Learning to See: Value Stream Mapping to Add Value and Eliminate Muda. Massachsetts: Lean Enterprise Institute.

Schumpeter, J. (1934). The theory of economic development: an inquiry into profits, capital, credit, interest, and the business cycle. Cambridge: Harvard University Press.

Schumpeter, J. (1996). Ensaios: empresários, inovação, ciclos de negócio e evolução do capitalismo. Oeiras: Celta Editores.

Silva, M.A. (2020). Testemunho de um agricultor de agricultura convencional. In Costa, C. A. (Coord). Pontes entre a agricultura familiar e a agricultura biológica. Centro de Estudos Ibéricos, Iberografias 37, 53-56. 
Spacek, M. \& Vacik, E. (2016). Company value creation through effective innovation process management. Journal of Innovation Management, 4(3), 65-78.

Stenberg, J. A. (2017). A conceptual framework for integrated pest management. Trends in plant science, 22(9), 759-769.

Suárez-Barraza, M.F., Smith, T., \& Dahlgaard-Park, S.M. (2012). Lean Service: A literature analysis and classification. Total Quality Management 85 Business Excellence, 23(3-4), $359-380$.

Suess-Reyes, J., \& Fuetsch, E. (2016). The future of family farming: A literature review on innovative, sustainable and sucession-oriented strategies. Journal of Rural Studies, 47(A), 117140 .

WCED. (1987). Our Common Future. World Comission on Environment and Development. New York: Oxford University Press.

Womack, J. P., Jones, D. T., \& Roos, D. (2007). The machine that changed the world: the story of lean production; Toyota's secret weapon in the global car wars that is revolutionizing world industry. New York: Free Press.

Womack, J.P., \& Jones, D.T. (2003). Lean Thinking. New York: Simon \& Schuster.

Yin, R. (1994). Case study research: Design and methods. Thousand Oaks: Sage Publications.

Zu, X., Fredendall, L. D., \& Douglas, T. J. (2008). The evolving theory of quality management - The role of Six Sigma. Journal of Operations Management, 26(5), 630-650. 


\section{Biographies}

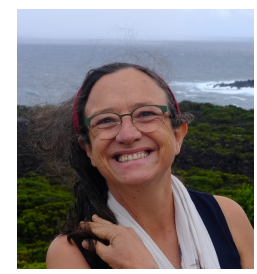

Ana A. Aguiar. Ana Aguiar has a PhD in Agricultural Engineering from the School of Agriculture of the University of Lisbon in Portugal, graduation in Agronomy Engineering and Master in Pest Management. The focus of her PhD thesis was "Pest risk management". She was agricultural entrepreneur for 6 years. Currently she is Assistant Professor at Faculty of Sciences at University of Porto and develops research in integrated pest management. She wrote several scientific papers in plant protection namely in pest risk assessment, decision making and control methods.

CRediT Statement: Conceptualization ; Methodology; Writing original draft.

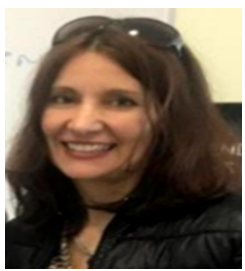

Luísa Silva. Luísa Silva has a master's degree in Agronomic Engineering from the Faculty of Sciences of Porto, in 2018. She started his professional career as administrative-financial, after finishing his degree in Business Management in 1996. She is enrolled in the Order of Certified Accountants, and currently responsible for several microenterprise accounts. In 2011, she decided to create Formtivity, Lda, a professional training and consulting company in the agricultural area, where she is CEO. In his spare time, she enjoys practicing yoga, reading and being with the family.

CRediT Statement: Investigation; Resources; Writing review and editing.

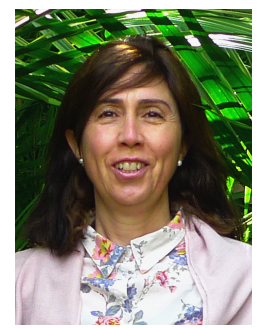

Cristina Parente. Sociologist and Associate Professor with tenure of the Faculty of Arts. Fellow Researcher of the Institute of Sociology of the University of Porto (UP), she currently is the director of Sociology Graduation. PhD (2004) and B.A. (1990), both in Sociology at the UP. M.A. (1996) in Human Resources Politics and Management in ISCTE, University Institute of Lisbon. Post-Doc in Administration (2012) in the Centre of Post-Graduation in Administration Researches of the School of Economic/Federal University of Minas Gerais (Brazil). In 2015, she developed a research on ""The ecosystem of the Solidarity Economy "", Institute of Government and Public Policy- IGOP, Autonomous University of BarcelonaUAB, integrating the Solidarity Economy Network Catalana-XES. She conducts activities both as researcher and scientific coordinator and supervisor of projects about social and solidarity economy, popular economy, agroecology, entrepreneurship, human resources management and organizational change. She supervises and co-supervises several Master and PhD in Portugal and Brazil. She is author and co-author of several scientific articles in peer review journals, books, oral presentations and conferences in both academic and professional events.

CRediT Statement: Conceptualization; Methodology; Writing original draft.

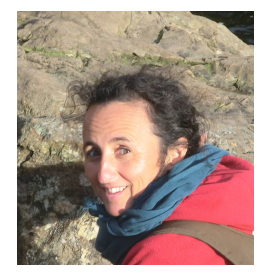

Cristina A. Costa. Associate Professor at the Agrarian School of the Polytechnic Institute of Viseu. She holds a MSc in Integrated Pest Management and a PhD in Agriculture Engineering from the School of Agriculture of the University of Lisbon. Her intervention and research areas are organic farming and integrated protection, economic valuation of the environment, with a focus on family farming and women farmers, both at national and European level. She is also a beekeeper whenever she has the time.

CRediT Statement: Writing review and editing.

\section{ISSN 2183-0606}

http://www.open-jim.org

http://creativecommons.org/licenses/by/3.0 